\title{
A MODEL APPLICATION OF MICRO GRID: BATMAN UNIVERSITY MICRO GRID
}

\author{
Mehmet Eşref Demir 1, Musa Yilmaz *2, Ahmet Gündoğdu2 \\ ${ }^{1}$ Turkish Petroleum, Batman/Turkey \\ ${ }^{2}$ Batman University Technology Faculty \\ Electronic and Communication Engineering, Batman/Turkey \\ *Corresponding author; musa.yilmaz@batman.edu.tr
}

\begin{abstract}
Micro-grids based on renewable energy such as wind, water and sun are high potential for emissionless power in future power systems. This article analyzes the possibility of developing a simple micro-grid model with optimal use of local renewable energy for Batman University's western ramen campus on the existing grid. The operating states of the designed micro-grid system are defined by the fact that they are not connected to or connected to the existing power grid and that the intermittent nature of solar, wind energy production is taken into consideration. For this reason, batteries, electrolyser-fuel cells are also used here for the continuity of the quality of the power, reliability and excess energy storage. In this study, hybrid power generation systems which constitute micro grid and micro grid are discussed. Then The Batman University western raman campus micro grid model, which includes the features mentioned, has been proposed and mentioned its applicability.
\end{abstract}

Key words: micro grid, applications of micro grid, renewable energy

\section{Introduction}

Parallel to the increasing population and developing technology, a technology called smart grids has emerged in the wake of the need to transform existing networks and power systems into more intelligent constructions, which can be more easily controlled using new information and telecommunication technologies. Power systems, electrical transmission and distribution networks, electricity generation systems can be continuously monitored with the technologies provided by smart grids. One of the most critical features of smart grid architecture is distributed generation and microgrids. In the present electricity grid, the electricity production center was located in very large power plants. However, thanks to the new generation electricity generation technologies (photovoltaic panels, wind turbines, etc.) developed today, distributed production can be realized from small and mediumsized power generation centers. Distributed generators of this kind allow the micro grids to survive a certain period of time with their own electricity, theoretically at such moments of crisis, by providing 
flexibility to the utility grid in the event of general breakdowns or natural disasters that may occur in the utility grid. Micro grids can also be a grid-independent structure of renewable energy sources (wind, solar, micro-hydropower, etc.) in small settlements such as holiday villages remote from energy distribution grids or residential areas to meet electricity demand.

The following studies were carried out on the micro grids in the research done

The micro grid is a grid that can contain a part of the medium / low voltage distribution system and the load group required by one or more distributed energy generation systems. The operation and control mode of the micro grid depending on the grid or independent from the grid varies depending on the power interaction with the main system of the micro grid. A micro-grid can be installed to meet the needs of several industrial facilities, university campuses and shopping centers. At the same time, in many homes, urban or rural areas, micro-grids can be built to feed small powerful consumers [1].

In the general structure of a micro-grid, there are generators such as micro-turbines, solar cells, fuel cells and wind turbines, which are usually less than 100 kilowatts in size, and storage or rectification circuits, inverters, controllers, protection circuits and filter circuits of various types [2].

Systems producing at $5 \mathrm{MW}$ and below are small, powerful distributed energy generation systems. In these systems, the electrical energy is not conducive to providing power directly to the existing network. Fuel cells, photovoltaic panels, micro wind turbines and storage units generate direct current; internal combustion diesel generators, wind turbines, gas turbines and micro hydroelectric power plants produce alternating currents with variable frequency $[3,4]$.

The problems encountered in the transfer of energy produced in renewable energy sources and actively generating electricity generation are addressed [5].

In smart grids, large scale domain management is being done with distributed control applications, and future approaches are being put forward [6].

It has been investigated that the efficiency of the micro grids based on the distributed generation as envisaged as the future grid model is higher than that of the large power plants and that the power shortages are minimized in the case of close to the consumer [7].

Application methods of battery energy storage technology, contribution to electric power system network operation and evaluation of its effects, current and economic feasibility [8].

In this study, a micro grid structure and a distribution automation structure are presented that allow the common use of renewable energy sources in low voltage settlement areas. The proposed approach has been considered to provide adaptation to the traditional distribution networks of renewable resources at minimum cost [9].

The current and future development of micro-grids in China has been examined. The current status of renewable energy sources and micro-grids in China and micro-grid topologies is addressing [10].

This article reviews the concept and background of a micro-grid, the current state of the literature, ongoing research projects and relevant standards. At the same time, it reviews the world's micro grid pilot projects in more detail and discussing potential ways to further research [11]. 
This paper investigates technical issues related to stable and autonomous operation of a microgrid composed of renewable power sources. Micro hydropower unit and wind farm renewable energy production systems are included in the micro grid. This system has been studied and simulated in different modes. The necessary control techniques for stable and automatic operation of the system at the desired voltage and frequency values are presented [12].

Numerous researches have been done on photovoltaic effect, wind energy and fuel cell in renewable energy systems. In this study, residential application of hybrid energy system consisting of photovoltaic, wind, fuel cell installed in Denizli clean energy house is being investigated. The electrical energy generated from the hybrid energy system was analyzed on the basis of DC distribution and consumption and power analysis was performed with fluke-43B power analyzer [13].

\section{Method}

Micro-grids and the power generation sources, storage units, electrolysers, fuel cells that are frequently used in the hybrid power generation system will be examined. Advantages and disadvantages of installing micro networks in AC, DC, AC-DC will be discussed. Afterwards, some studies will be examined and a sample micro grid will be evaluated.

\subsection{Micro Grids}

The micro grid is a structure that is a part of the distribution grid in which there are distributed resources can operate autonomously and is applied to the part of the utility grid generally covering the low voltage distribution substation and the latter. In a mixed grid architecture consisting of distributed generators, a micro grid system that provides a control scheme and simplicity appears to be a single control unit when connected to the utility grid. Often the attachment of energy sources to the system's inverter interface is one of the most prominent features of scattered production. For this reason, the control of the inverters in terms of the quality and continuity of the generated power arises among other important points of the scattered production.

\subsubsection{Structure of Micro Networks}

The most general description of the micro-grid is explained by a community created by members of the European Union and micro-network projects it has realized [14]. Accordingly, micro-grids consisting of distributed generators including renewable energy sources, controllable loads, energy storage units, and a structure that can operate in a grid-dependent or grid independent mode, are the grid components performed at the low voltage level of the electricity grids. Figure 1 shows a typical micronetwork architecture [15]. The main distributed energy sources in the micro-grid are photovoltaic systems, wind turbines, micro turbines, fuel cells and diesel generators. Super capacitors and superconductor inductances, primarily flywheels and energy batterys, are commonly known as energy storage units, emerging as alternative new technologies. The control systems of the micro-networks consist of local controllers (MC: micro-source controller, LC: load controller) and a central controller (MGCC) as shown in Fig.1. 


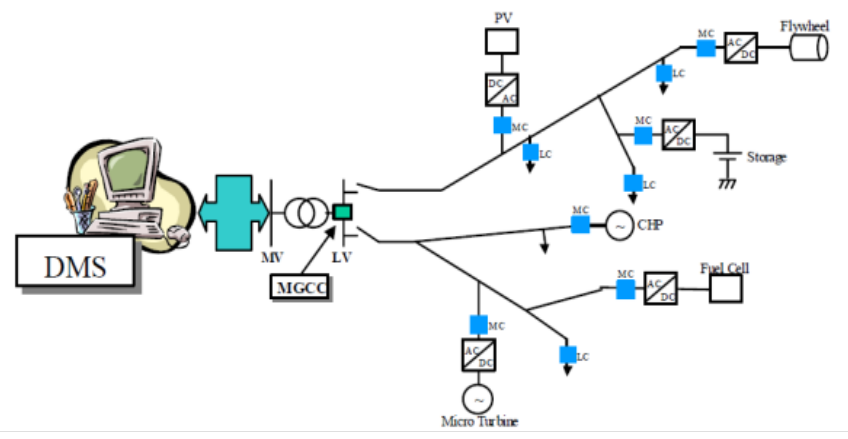

Figure 1. A Typical Micro Grid Architecture [15]

The task of the central controller is system coordination, while micro-grids are usually designed to allow the system to run with local controllers at the minimum level. Micro-grids can have different topologies. Congestion in the transmission lines can be avoided by placing a large number of distributed energy sources near the load center. Thanks to the distributed energy sources placed close to the loads, it is possible to increase the load in the local consumer areas. Small hydro, medium-sized wind / photovoltaic production fields, biomass and biogas-fueled energy production are some of the alternative energy sources. Thanks to the micro-grids consisting of alternative energy sources, the connection of the high voltage grid to the utility grid can be cut off in a coordinated manner and planned maintenance can be realized in high voltage lines and transformer centers. Prevention of short or long-term energy interruptions is possible with planned micro-grid islands.

Feeding with high quality energy is an indispensable need for industrial loads. A micro-grid can be designed to meet the needs of several industrial plants (shopping malls, university campuses, industrial premises, etc.). In the micro-grid, the elimination of momentary power failures and the increase in power quality by reducing the adverse effects of adjacent consumers or the main grid can be achieved with control and automation support.

Micro-grids can be used in the production of electric energy, distributed energy sources such as small hydro, wind turbine, solar energy and low emission gas turbines, etc. considering the geographical characteristics of the region. Because of the large differences between the minimum and maximum loads in the area where the micro-grid will be installed, technical selection, sizing and deployment of distributed energy sources are important.

\subsubsection{Hybrid Power Generation System}

Hybrid energy production system are units that contribute to each other in parallel and micro-grid systems that perform energy production from at least two or more raw energy sources. The purpose of establishing hybrid systems is to increase both the efficiency and to meet the energy demand of the system by providing energy sources together in case of absence or decrease of one of the energy sources. The fact that the source of the region where the energy is to be generated is at a sufficient level and that there is a sufficient level of technology to bring the system together in some types of energy sources is 
the most important factor determining the number of sources and the type of source in hybrid applications. Energy sources such as hydrogen, biomass and fuel cells are examples of such situations. At the same time, hybrid systems can be combined with energy storage units to increase the duration of energy production and reduce system cost. Therefore, the main system components that make up the micro grid are; photovoltaic power generation system, wind power generation system, micro hydropower generation system, storage units, electrolyser and fuel cell units are explained individually.

\subsubsection{Wind Power Generation System}

The wind is generated by heating the surface of the solar radiation at different degrees. The temperature, the humidity and the pressure of the air are different, and the result of the movement of air in these different pressures is due to the different warmth of the space. Some of the wind energy is obtained by turning about $2 \%$ of the solar energy reaching the earth. For investment in the economic wind power plant (Res), a wind speed of $7 \mathrm{~m} / \mathrm{s}$ or more at a height of $50 \mathrm{~m}$, a capacity factor of $35 \%$ or more is required. Considering the areas with these conditions in our country, it is accepted that a wind power plant can be installed at an average power of $5 \mathrm{MW} / \mathrm{km}^{2}$. With these acceptances, the wind power potential in our country has been determined as $48.000 \mathrm{MW}$ installed power. $1.3 \%$ of Turkey's total surface area is the area corresponding to this potential [16]. Wind energy is a type of energy that has to be consumed at the place of production or given to the interconnected grid. Since the energy production of wind energy conversion systems (wind turbine) depends entirely on the wind, such systems can only be installed in windy regions. The difference between production and consumption times is one of the most obvious problems of wind energy. This problem can only be solved by storing energy at this time.

\subsubsection{Photovoltaic Power Generation System}

Turkey's total annual average sunshine time of 2,640 hours, the average annual solar radiation of $1,311 \mathrm{kWh} /$ year per square meter that Electrical Power Resources Survey Administration are indicated by. If the potential amount specified for our country is fully exploited, an area of only $144 \mathrm{~km}^{2}$ will be sufficient to meet the annual electricity demand of 190 billion kWh. $12 \mathrm{~km} \mathrm{x} 12 \mathrm{~km}$ as the size of the specified area is less than 1/5000 of the surface area of Turkey. Even if it is the theoretical level that solar energy technology applications have a lot of importance in solving the energy problem of our country, it is understood from these striking figures [17]. The electricity generation of the photovoltaic cell is represented as a source of current. Naturally, as the radiation falling on the cell increases, the electric current also increases. The body of the photovoltaic cell is modeled with diode as it is made of semiconductor material. The losses and crystal defects that occur during the transfer of the energy produced in the P-n junction to the boxes are represented by serial resistances and parallel resistances, respectively. The electrical equivalent circuit of the photovoltaic cell is modeled in Fig. 2. 


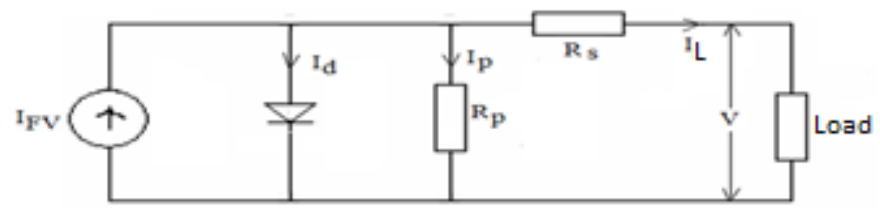

Figure 2. Photovoltaic Cell Electrical Equivalent Circuit Model

Modules are formed by parallel or series connection of photovoltaic cells with each other. Depending on the power requirement, the modules are connected in series or parallel to each other to form a photovoltaic panel. Photovoltaic array is obtained by parallel or serial connection of panels. In this way, the photovoltaic system can be formed with the desired power with solar energy. Figure 3 shows cell-module-panel-array stages of a photovoltaic system.

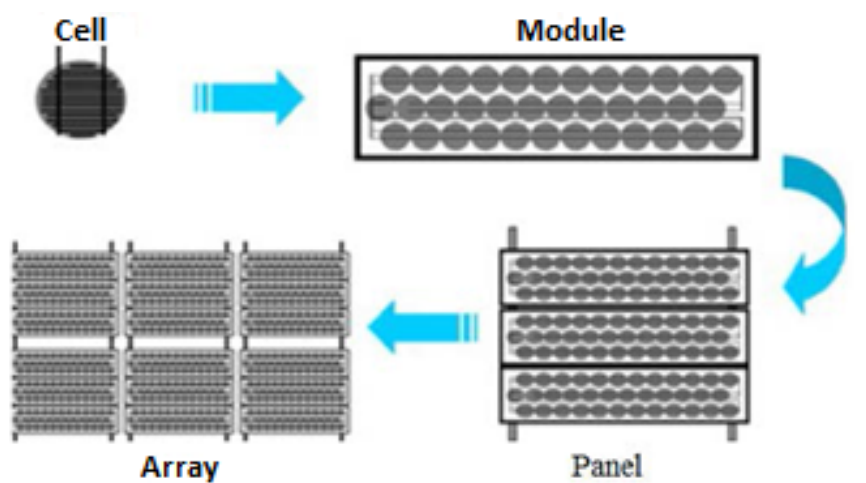

Figure 3. Photovoltaic Cell-Array Stages

It is possible to see the sun in the best conditions from sunrise to sunset in order to be able to benefit from the sunlight in the year. The current from any modulator is directly proportional to the falling solar radiation. As the amount of sunlight increases, the amount of electricity generated will also increase. Figure 4 shows the voltage-current and voltage-power curves at $25^{\circ} \mathrm{C}$ in the photovoltaic module.
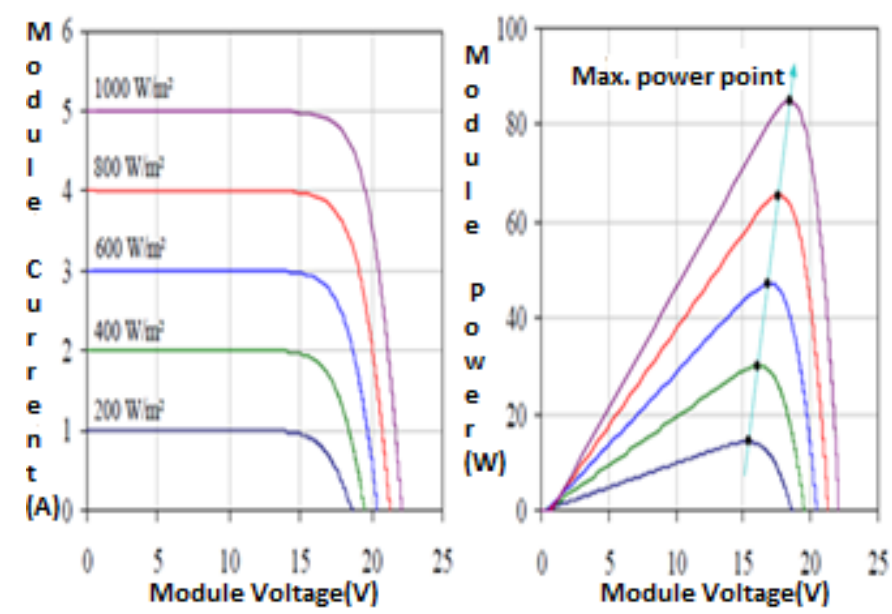

Figure 4. Current-Voltage and Voltage-Power Curve in Different Solar Lights 


\subsubsection{Micro Hydroelectric Power Generation System}

Hydraulic energy from renewable energy sources is the most common type of energy used since long ago. The hydroelectric power generation system is based on the conversion of the potential energy of water into electrical energy. The water that is accumulated in the dams is poured from high and cast into turbine. The turbine is rotated along with the bombardment, so that the potential energy of the water is converted to mechanical energy. By means of this mechanical energy, the generator shaft is rotated to obtain the voltage at the generator. The schematic of the micro hydroelectric power plant is shown in Figure 5.

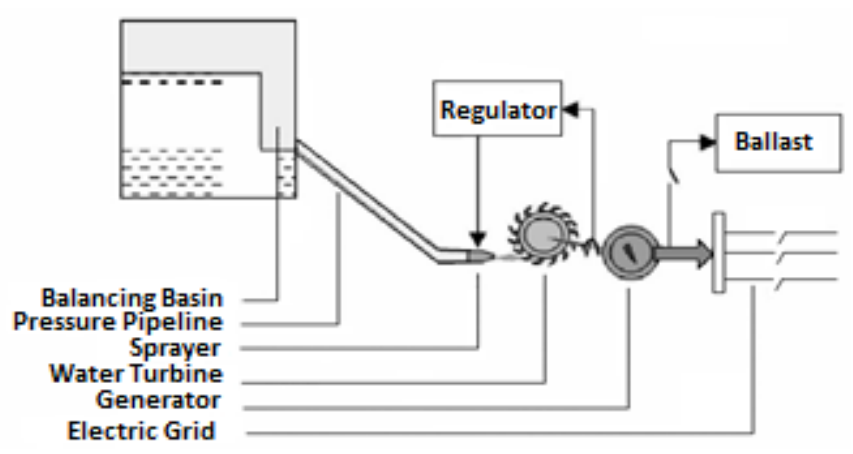

Figure 5. Micro Hydroelectric Power Plant Schematic [18]

Storage Units

Energy storage technologies differ chemically, mechanically and electrically. Considering the cost-efficiency ratio, the most appropriate type of technology is selected from among them. Energy storage practices can be broken down into categories to answer two basic needs.

Energy-based applications: If necessary, the response time (commissioning) is the storage applications which can be reasonably estimated to be around one minute, excluding very sensitive loads, requiring several hours of service (discharge) time and responding to long-term energy demand.

Power based applications: It is the storage applications that are used to improve the quality of the power rather than the load requirement. Correcting power quality refers to eliminating unwanted conditions such as suppression of sudden power and voltage changes and achieving target grid frequency stability. Generally, a long service period is not required (usually less than 1 hour) and several minutes of service can be accepted according to demand. In these applications, the response time (entering the circuit) is expected to be in the order of ms.

Considering the diversity of energy storage usage and the multiplicity of usage areas, the different energy storage technologies used in power systems can be listed as follows.

Conventional batteries [lead-acid (Pb-Acid) batteries, nickel cadmium (NiCad) batteries], improved batteries [Lithium Ion ( $\mathrm{Li}$-ion) batteries, Sodium Sulfide ( $\mathrm{NaS})$, Zebra (NaNiCl) batteries], flow batteries [Vanadium Redox Batteries (VRB), Zinc Brom Batteries ( $\mathrm{ZnBr}$ )], pumped hydropower 
based storage, energy storage with compressed air, energy storage with hydrogen, flying wheel / flywheel energy storage, supercapacitor/ultracapacitor, superconducting magnetic energy storage (SMES).

In a daily supply-demand balance in the power plant, the excess energy produced during the hours when the demanded power value is at a value well below the generated power can be stored in the storage units with the energy storage system and a portion of the demand can be met from the pre-stored energy for the duration of the peak demand value. This prevents the operation of the production units over their capacities at certain intervals, thereby contributing to the reduction of the transmission and distribution losses and the prolongation of the operating life with optimum efficiency. With energy storage, if there is a multi-time scheduled billing, while the tariff is cheap, storage is done and while the tariff is expensive, part of the demanded power is taken from the storage unit and the remaining part is taken from the utility grid so that economical saving is obtained. In addition, the cost of system installation can be reduced by analyzing the feasibility stage by lowering the peak demand value with the storage units. This practice is called arbitrage.

\subsubsection{Electrolyzer}

Hydrogen, a colorless, odorless, tasteless and transparent structure, is shown as an energy source for the future. It is not the natural state in the world and it is the smallest and lightest element on earth. It is a synthetic fuel that can be obtained from different raw materials such as water, air, coal and natural gas. Hydrogen is important because it can be easily stored in tanks and can be converted to electricity with high efficiency if necessary. The working principle of electrolyzers is the inverse of fuel cells. The main electrolytes are the Proton Exchange Membrane (PEM), solid oxide and alkali electrolyzers. Two types of these electrolyzers are commercially used.

Alkaline electrolyser; is commonly used in liquid electrolytes which are widely known today. The impurities of oxygen and hydrogen gases obtained in alkaline electrolyzers and the reduction of their efficiency due to the corrosion of the electrode layers over time during operation are major disadvantages in alkaline electrolyzers. [19].

PEM electrolyser; is the most preferred type of electrolyser having advantages such as high performance operation, high pressure hydrogen production, compacted portable structure and high purity hydrogen production. The water and electricity requirements of the electrolyser are met by pump and power supply, respectively. PEM electrolyzers have cathode and anode parts as in fuel cells. In the anode part, water is separated into oxygen gas, hydrogen ion, and electrons. Electrons are attracted by the power supply. Hydrogen ions pass through the polymeric membrane, where only the proton can pass, to the cathode. Hydrogen gas is formed by the combination of these hydrogen ions with the electrons coming from the power source. As a result, the hydrogen gas is generated in the cathode, oxygen gas is generated in the anode. 


\subsubsection{Fuel Cell}

The fuel cell, which is a kind of battery, is an electrochemical energy conversion system in which the chemical energy is directly converted to heat and electric energy. Generally, hydrogen is used as fuel. Power generation in the fuel cell occurs by electrochemical reaction between oxygen and hydrogen. Fuel cells consist of an electrolyte and a pair of electrodes, as shown in Figure 6.

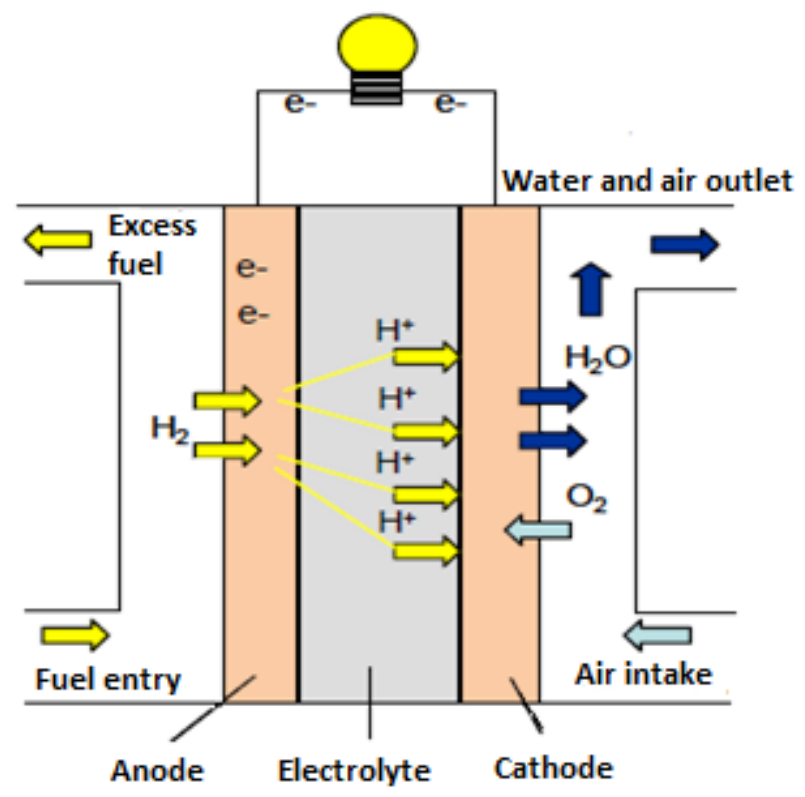

Figure 6. Fuel Cell Basic Structure [20]

Proton Exchange Membrane Fuel Cell (PEMFC), Phosphoric Acid Fuel Cell (PAFC), Alkaline Fuel Cell (AFC), Solid Oxide Fuel Cell (SOFC) and Molten Carbonate Fuel Cell (MCFC) are the most common fuel cell technologies. The main difference between them is the electrolyte, which has many effects on the operating and design characteristics of the fuel cell. Fuel cells form a direct current (DC) and a voltage direct proportional to the number of serial cells. The value of the voltage produced varies with the wear of the fuel cell and the load over time. Alternating current and voltage (AC) can then be obtained by a power regulator having DC / AC conversion, voltage, current and frequency control. The fuel cell meets the internal energy needs such as fans, pumps and control system, as well as the power requirements of the outdoor environment.

\subsection{A Model Application of Micro Grid: West Raman Campus of Batman University Micro Grid}

According to Batman province global solar radiation distribution map, it is seen that the average value is generally $1600-1650 \mathrm{KWh} / \mathrm{m}^{2}$-year on a yearly basis, according to the Ministry of Energy and Natural Resources Renewable Energies General Directorate. Figure 7 shows the daily values of global radiation amounts and sunbathing times according to the month of Batman. Figure 7 shows that it is 
suitable for electric energy production with photovoltaic panel except November, December, January and February.

It should be remembered that although sunlight periods and radiation values are high in summer, high photovoltaic panel temperature affects system efficiency negatively. According to the month shown in Figure 7, daily global radiation values are very important in the design of the photovoltaic system in the micro-grid that we think.
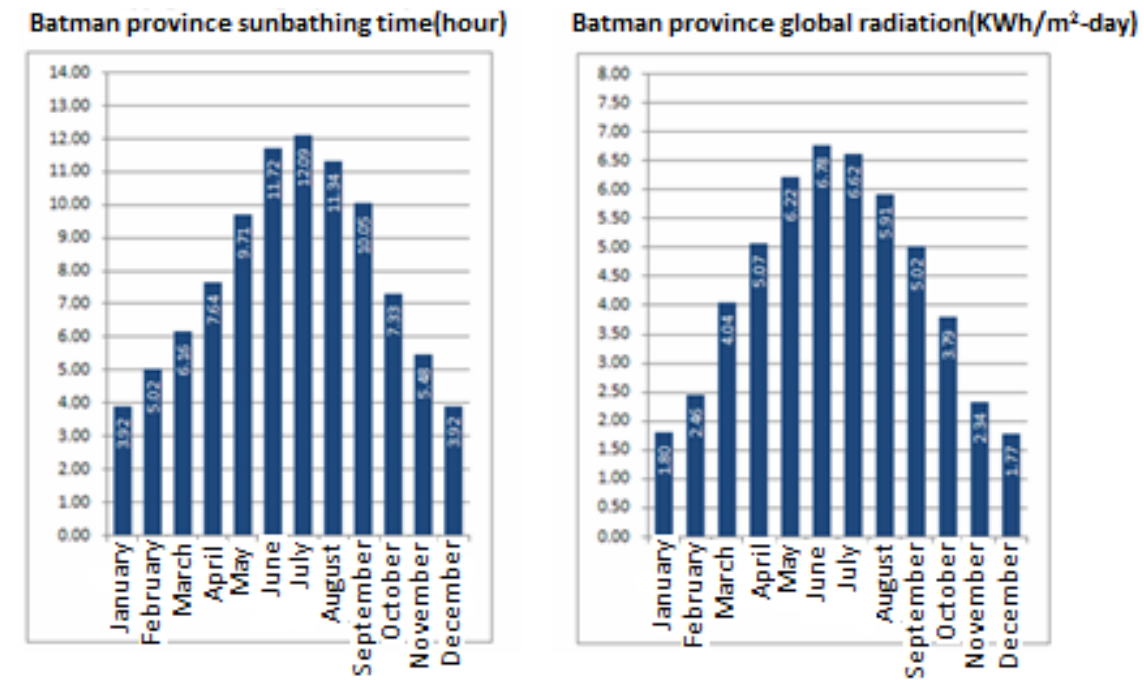

Figure 7. Batman province sunbathing time and global radiation values [21]

Figure 8 shows the Batman wind speed distribution at a height of 50 meters and Batman University's western raman settlement location is marked here. Accordingly, it is seen that the wind speed at the specified position is $4 \mathrm{~m} / \mathrm{s}$. According to the Ministry of Energy and Natural Resources Renewable Energies General Directorate, the capacity factor at the height of $50 \mathrm{~m}$ is $10 \%$. For investment in the economic wind power plant (WPP), a wind speed of $7 \mathrm{~m} / \mathrm{s}$ or more at a height of 50 $\mathrm{m}$, a capacity factor of $35 \%$ or more is required. For the micro-grid position we think it can be done on a small scale for research purposes, although this data does not seem to be suitable for large-scale economic WPP investments. 


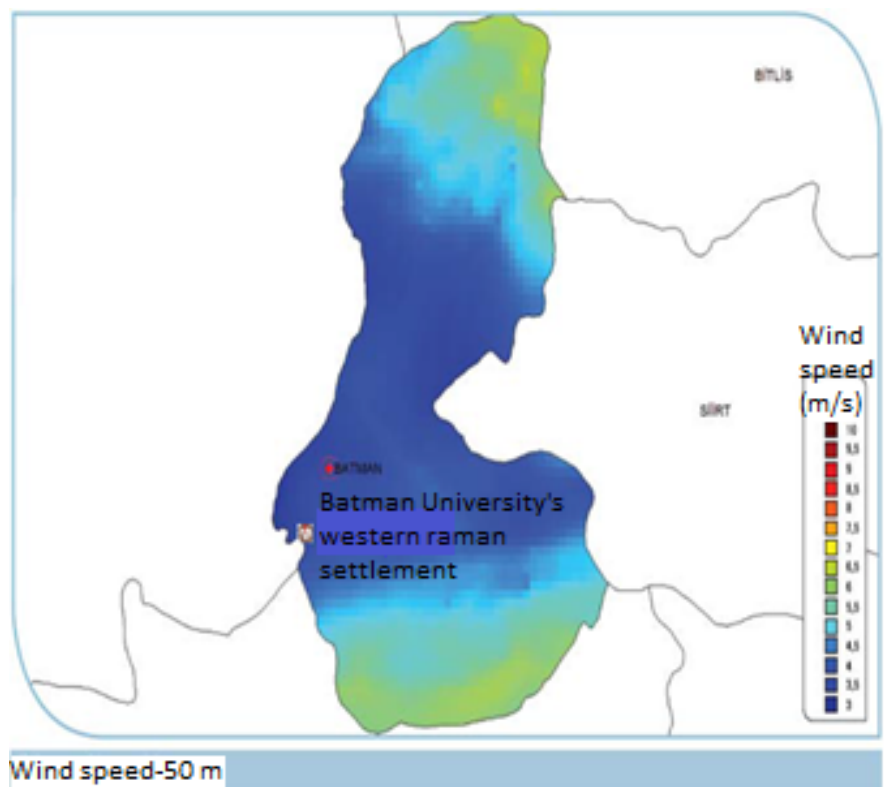

Figure 8. Batman province wind speed distribution - 50 meters high [22]

Table I. Batman University's Western Raman Settlement Monthly Electric Consumption Quantity [Dedaş]

\begin{tabular}{|c|c|}
\hline Billing Date Range & Energy Consumption Amount \\
\hline $21.12 .2015---21.01 .2016$ & $440606 \mathrm{kwh}$ \\
\hline $21.01 .2016---21.02 .2016$ & $420210 \mathrm{kwh}$ \\
\hline $21.02 .2016---21.03 .2016$ & $307326 \mathrm{kwh}$ \\
\hline $21.03 .2016---21.04 .2016$ & $292698 \mathrm{kwh}$ \\
\hline $21.04 .2016---22.05 .2016$ & $235318 \mathrm{kwh}$ \\
\hline $22.05 .2016---20.06 .2016$ & $260682 \mathrm{kwh}$ \\
\hline $20.06 .2016---23.07 .2016$ & $321982 \mathrm{kwh}$ \\
\hline $23.07 .2016---22.08 .2016$ & $375498 \mathrm{kwh}$ \\
\hline $22.08 .2016---22.09 .2016$ & $311383 \mathrm{kwh}$ \\
\hline $22.09 .2016---22.10 .2016$ & $290517 \mathrm{kwh}$ \\
\hline $22.10 .2016---22.11 .2016$ & $338100 \mathrm{kwh}$ \\
\hline $22.11 .2016---21.12 .2016$ & $415380 \mathrm{kwh}$ \\
\hline
\end{tabular}

In Table 1, monthly energy consumption amounts of Batman University west raman settlement taken from Batman province Dedaş Directorate are given over the last year. It is observed that energy consumption is mostly in the winter season, that is, it is in December, January, February, and it is mostly in the summer season, that is, it is in August. During the winter months sunning and solar radiation value is low but the amount of precipitation is high. As shown in Fig. 9, a micro-hydropower plant is considered in the micro-grid to close the energy gap in these months, on the Dicle river basin passing near it.

The main branches of the Dicle River are Batman and Garzan, Habur, Botan, Great Zap and Little Zap. The discharge is about $360 \mathrm{~m}^{3} / \mathrm{sec}$. It shows a big change between $55 \mathrm{~m}^{3} / \mathrm{s}$ in mid-September 
Vol 2, Number 2, 2017

ISSN: 2548-0332

doi: 10.23884/IJESG.2017.2.2.04

and $2263 \mathrm{~m}^{3} / \mathrm{s}$ at the end of February. In the river, the water is usually reduced due to late summer drought and low rainfall at the beginning of autumn. Despite this, the stream rises with the end of winter rain and the snow at the beginning of spring. [23]. The discharge of river plays an important role in the design of micro hydropower.

Battery and energy storage are also considered for hours when energy production is intensive but energy needs are low. When a good power analysis is performed, the maximum power point can be pulled down by energy storage, so the system installed power can be reduced and the cost can be reduced. It can also be used as a charging station in ar-ge work such as electric vehicle which is considered to be made in the future with suitable battery selection.

In the same way as the battery, the electrolyzer, hydrogen storage and fuel cell units are also considered to be used in the fuel cell, if necessary, by storing the hydrogen with the electrolyzer at a time when the energy production is much more than the energy consumption. These units can also be used for future research.

In this study, a hybrid micro-grid consisting of wind turbine, micro hydro-power plant, photovoltaic panel, battery, fuel cell and electrolyser is shown in Fig. 9, where grid-connected or gridunconnected renewable energy sources are used. The micro-grid in operation is considered for Batman University's west raman campus.

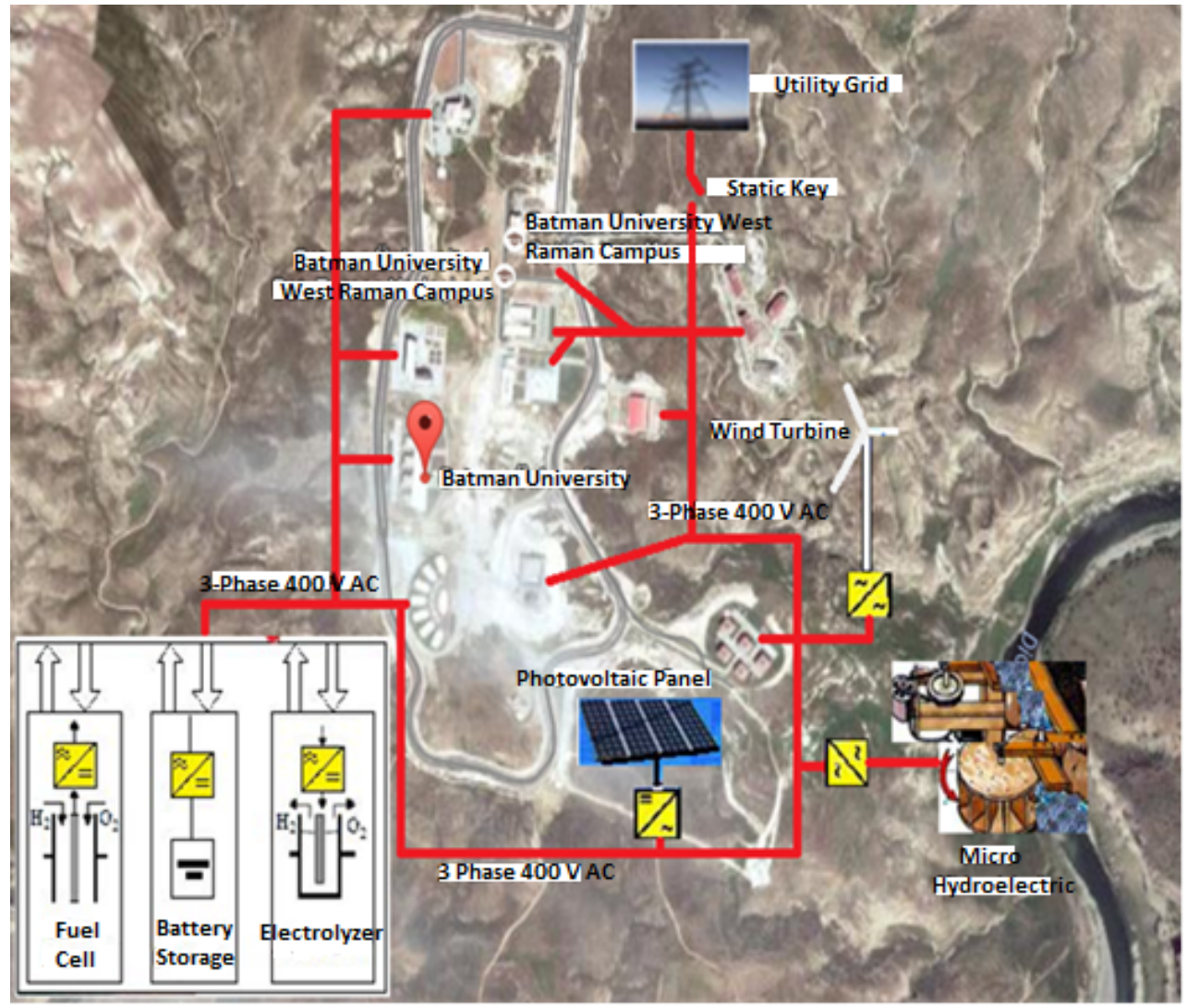

Figure 9. Batman University West Raman Campus Micro Network

In Table 1 it is seen that monthly energy consumption amount is maximum $440606 \mathrm{kWh}$. When this amount is calculated on a daily basis, $440606 / 30$ is about $14687 \mathrm{kWh}$. In our hybrid micro-grid 
design, $14687 \mathrm{kWh}$ can be taken as the maximum daily consumption. While there is no energy storage installed value, this consumption is the maximum consumed hours in hours during the day. This value can be found by looking at the consumption values in the day. Similarly, the minimum daily consumption of 235318/30 is approximately $7844 \mathrm{kWh}$. Hybrid micro network cost can be reduced by energy storage units to be used after power analysis. Energy storage in the hybrid micro grid system can be done from the utility grid at times when energy production and tariff are low; it can be done from the micro grid system at times when energy production is intense and consumption is low. This can be accomplished with energy management software that covers situations such as cost, energy consumption, reduced installed power level in a hybrid micro grid system.

Considering the energy consumption amounts in table I, energy consumption contents, energy consumption distribution in the average day, the values of wind - sun for Batman province, the datas of Dicle river passing near Batman university western raman settlement and additional energy consumption to be added in the campus in future, the characteristics of the units to be used in the system can be determined.

The micro grid shown in Figure 9 feeds Batman University's western raman campus area. The low voltage (LV) line to be used to meet load requirements is designed as three phase $(400 \mathrm{~V}, 50 \mathrm{~Hz})$. The battery, the fuel cell and the electrolyser units are connected to the AG line via the necessary converters. Likewise, photovoltaic panels, wind turbines, micro hydropower plants are connected to the line via the necessary converters. Micro grid and utility grid connection are made with required units when requested.

Energy management, which can be done in a renewable energy-based micro-network, can be achieved by loading the electrical energy that is produced by hybrid connection of the production resources or storing it in the storage unit (battery or super capacitor) for use in case of need. At the same time, with this energy management, if the battery is full, the surplus energy generated can either be transferred to the utility grid or can be directed to electrolysis for hydrogen production which can then be used in the fuel cell. A charge regulator is used to prevent the battery from overcharging or overdischarging. Generally, the minimum charge is $40 \%$ and the maximum charge is $80 \%$ to protect the battery.

When the sources of power generation produce less power than demanded, the missing energy must be supplied from the battery, the fuel cell or the network according to the charging status of the battery, and the battery must be recharged.

In addition, when the sources of power generation do not produce energy and the battery is empty, the energy needed for the load must be met from the fuel cell or the utility grid and the battery must be recharged.

When the generated energy and load demand are equal, the battery charge status will remain the same. There will be no need for any energy exchange from the utility grid.

The mentioned situations can be done with energy management software that can be developed. Thus, it is aimed to have a continuous flow of energy between power generation units and load and utility grid. At the same time, the storage unit will be able to be used in the charging of electric vehicles in the case of the use of rapidly deployed electric vehicles in the developing technology. 
The micro grid designed in Fig. 9 can also be considered as a block-based DC micro grid as shown in Fig. 10. DC micro-grids have many advantages when compared to AC micro-grids. The system is an intelligent DC micro-grid that can be remotely monitored and controlled, with a grid-connected photovoltaic panels and energy storage units, which was first built in a building in China and able to meet different needs. In the coming days, the car charging station is also considered, considering the increased use of electric vehicles.

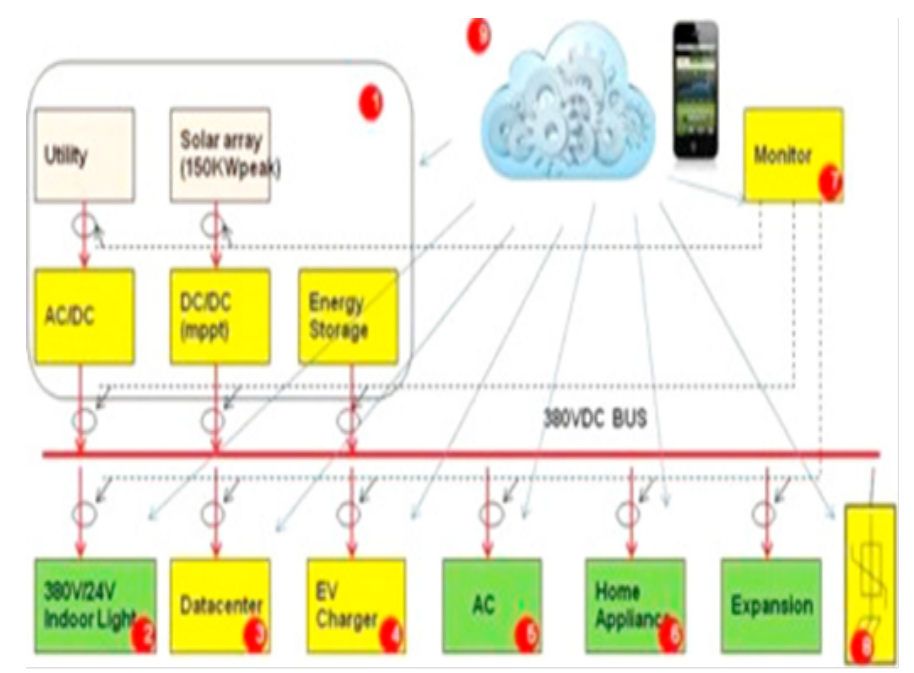

Figure 10. Structure of a building application with photovoltaic integrated DC micro grid [24]

\section{Findings}

Micro-grids, which have an important place in intelligent grids, can be realized distributed production from small and medium-sized electricity production centers at the level of low voltage. In the case of general breakdowns in the utility grids or in the case of natural disasters, the type of distributed production centers can be partly or wholly self-sufficient with their own electricity generated in the independent mode from the utility network.

In the general structure of a micro-grid, there are generators such as micro-turbines, solar cells, fuel cells and wind turbines with a total power of less than $100 \mathrm{~kW}$, and storage or rectification circuits, inverters, controllers, protection circuits and various types of filter circuits for the use of energy produced there.

Micro-grids can be a islanded structure of renewable energy sources (wind, photovoltaic, microhydropower, etc.) to meet the electricity needs of small settlements such as villages and islands away from energy distribution grids or residential areas.

Thanks to the micro-grids, electricity generation can be done in a place close to the place where the energy need is instead of a big center. This eliminates the disadvantages such as energy loss, failures caused by overloading the grid, and it is possible to increase the load in local consumer areas. It offers many advantages from an economic point of view.

Congestion in transmission lines can be avoided by placing micro-grids of distributed energy sources near the load center. 
A micro-grid can be installed to meet the needs of several industrial facilities, university campuses and shopping centers. At the same time, in many homes, urban or rural areas, micro-grids can be built to feed small, powerful consumers.

When a micro grid system is connected to the utility grid it looks like a single control unit and provides a control hierarchy and simplicity within the complex grid architecture consisting of distributed generators. One of the most prominent features of distributed production is that resources are usually connected to the system by the inverter interface.

Thanks to the micro-grids consisting of alternative energy sources, the connection of the high voltage grid to the utility network can be cut off in a coordinated manner and planned maintenance can be realized in high voltage lines and transformer centers. Prevention of short or long-term energy interruptions is possible with planned micro-grid islands.

The elimination of momentary power failures in the micro-grid and the increase in power quality by reducing the adverse effects of adjacent consumers or the main grid can be achieved with control and automation support.

Micro-grids are usually made as AC micro-grids. However, because of the rapid growth of DC loads and DC sources in distribution grids, requiring no AC-DC or DC-AC conversions, having better stability as well as less losses, regardless of reactive power, and relatively less failure of the components inside, DC micro grids has begun to stand out. On the other hand, the original harmonic current in the $\mathrm{AC}$ grids can be weakened by pressing in the $\mathrm{DC}$ grids via interconnected converters, and the application of AC / DC micro grids improves harmonic compensation control due to the wide connection of the DC current in the DC micro grids.

In the AC / DC micro grid also negative and zero component currents due to unbalanced loads in the AC system can be absorbed by the DC micro grid.

\section{Conclusions and Recommendations}

The need for energy is increasing day by day, the rapid depletion of resources to meet energy demands, the global environmental awareness resulting from the increase of ecological problems, efforts to prevent threats to live life, conventional energy, renewable energies and harmonious coordination of these energy resources within the existing grid it requires work in the field of usage. This requirement reveals the concept of smart grids.

Smart grids aim at environmentally friendly energy based on the principle of minimum loss with maximum quality coming from the consumers and producers focused agenda. In this context, microgrids are grid services that are among the essential elements of smart grids and meet the energy needs of the consumer in optimum conditions of distributed energy sources.

Micro grids, which are composed of distributed generators, including renewable energy sources, controllable loads, energy storage units, and which are capable of operating in a grid-dependent or grid independent mode, are grid components at the low voltage level of the electrical grids. The main distributed energy sources in the micro-grid are photovoltaic systems, wind turbines, micro turbines, fuel cells and diesel generators. Super capacitors and superconductor inductances, primarily flywheels and energy batteries, are commonly known as energy storage units, emerging as alternative new 
technologies. With the software to be developed and the control mechanisms, the compatibility of the micro-grids with the main grid can be ensured.

Micro grids are quality, reliable, environmentally friendly and sustainable grids that provide energy production based on renewable energy sources rather than traditional grids. Transmission and distribution losses, operating and maintenance expenses are quite low because micro grids are close to the ultimate consumer. In addition, short time and easy construction make micro grids advantageous.

If the micro grids are grid dependent, it is necessary to design them for bi-directional load flow and to increase the protection and control elements.

Micro-grids should be extended due to the fact that they can operate in a grid-independent mode in the event of general breakdowns in the main system grids or in cases of disasters such as natural disasters, and the related researches should be done. Where necessary, legal arrangements to encourage and facilitate such work should be undertaken by competent authorities.

Social awareness should be established both on sectoral basis and public opinion with national and international symposiums, congresses, workshops etc. on smart grids and micro grids. Model studies conducted in countries such as Japan, China, America which are leading in this subject should be examined and expert human power should be created by sending technical delegation, academicians, etc. to these countries for educational purposes.

In these assessments, micro-grids are an important target of smart grids that stand out in the energy market. It is anticipated that the micro-grid transformations of traditional production networks and the technological developments in renewable energy sources will increase rapidly.

\section{References}

[1] Türkay, B., Dağıtılmış Enerji Kaynakları İçeren Şebeke Tasarım Önerisi. Ulusal Elektrik Tesisat Kongresi, İzmir Fuar Alan1, 2009.

[2] Parlak, K. Ş., Eviricilerden Oluşan Dağınık Güç Sistemlerinde Doğrusal ve Doğrusal Olmayan Yükler İçin Enerji Yönetimi. Doktora Tezi, Fırat Üniversitesi Fen Bilimleri Enstitüsü, Elazı̆g, Türkiye, 7, 2006.

[3] Özdemir, E. Dağıtılmış Enerji Üretim Sistemlerinden Elektrik Üretimi ve Şebeke Desteği Hizmetleri. IV. Yenilenebilir Enerji Kaynakları Sempozyumu Program1, Gaziantep, 118-123,2007.

[4] Akdeniz, E., Kaypmaz, A., Yağmur, E. A., Yenilenebilir Kaynaklardan Enerji Üretiminin Şebekenin Enerji Kalitesi Üzerine Etkilerinin İncelenmesi,2006, ELECO’2006 ElektrikElektronik-Bilgisayar Mühendisliği Sempozyumu ve Fuarı Bildirileri, Bursa.

[5] Akar, O., Terzi, K., Yapı Tabanlı Mikro Dağıtılmış Enerji Üretim Sistemleri. 3e electrotech dijital dergi, 2006. Retrieved November 9, 2016 from http://3eelectrotech.com.tr/arsiv/yazi/yapytabanly-mikro-dadytylmy-enerji-uretim-sistemleri

[6] Akçin, M., Alagöz, B.B., Keleş, C., Karabiber, A., Kaygusuz, A., Dağıtık kontrol ile akıllı şebekelerde geniş alan yönetimi ve geleceğe dönük projeksiyonlar. SAÜ. Fen Bil. Der., 17(3), 457-470, 2013. 
[7] Türkay, B., Dağıtılmış enerji kaynakları içeren şebeke tasarım önerisi. İTÜ Elektrik-Elektronik Fakültesi Elektrik Mühendisliği Bölümü.

[8] Özdemir, E., Çalıker, A., Koç, İ. M., Yenilenebilir enerji kaynağından beslenen elektrik güç sistemleri için hibrit enerji depolama teknolojileri. ICCI 2014.

[9] Dağ, B., Aydemir, M. T., Nadar, A. Yerleşim bölgeleri için evirici arayüzlü hibrid yenilenebilir enerji kaynakları içeren bir mikro ağ felsefesi.

[10] Zhu, X., Han, X., Qin, W., Wang, P., Past,today and future development of micro-grids in China. Renewable and Sustainable Energy Reviews, 42, 1453-1463, 2015.

[11] Ustun, T. S., Ozansoy, C., Zayegh, A., Recent developments in microgrids and example cases around the world-A review. Renewable and Sustainable Energy Reviews, 15, 4030-4041,2011.

[12] Ahshan, R., Iqbal, M.T., Mann, George K. I., Quaicoe John E., Modeling and Analysis of a Micro-Grid System Powered by Renewable Energy Sources. The Open Renewable Energy Journal, 6, 7-22, 2013.

[13] Cetin, E., Yilanci, A., Ozturk, H. K., Colak, M., Kasikci, I., Iplikci, S., A micro-DC power distribution system for a residential application energized by photovoltaic-wind/fuel cell hybrid energy systems. Energy and Buildings, 42, 1344-1352, 2010.

[14] Retrieved from http://www.microgrids.eu/index.php

[15] Retrieved from http://www.microgrids.eu/micro2000/presentations/19.pdf

[16] Rüstemli S., Çıbuk M., Oral F., Aydın M. C., Kocaman B., Güntaş Ö., Bitlis Eren Üniversitesi Yenilenebilir Enerji Kaynakları Raporu, 2013.

[17] Retrieved from http://repa.eie.gov.tr/MyCalculator/Default.aspx

[18] Ibrahim Bt N. A., Modelling of Micro Hydroelectric System Design. University Tun Hussein Onn, Master thesis, Malaysia,2012.

[19] Becerikli F., Yüksek Basınçlı PEM (Proton Geçirgen Membran) Elektrolizör Geliştirilmesi ve Çalışma Parametrelerinin Performansa Etkisi. Niğde Üniversitesi, Fen Bilimleri Enstitüsü, Yüksek lisans tezi, 75s., Niğde,2011.

[20] Mohd Zamri Che W., Dynamic Simulation and Intelligent Management of Distributed Generation. Universität Duisburg-Essen, Doctorate thesis, Malaysia, 2011.

[21] Retrieved from http://www.eie.gov.tr/eie-web/duyurular/YEK/gepa/BATMAN-GEPA.pdf

[22] Retrieved from http://www.eie.gov.tr/YEKrepa/BATMAN-REPA.pdf

[23] Retrieved from https://tr.wikipedia.org/wiki/Dicle

[24] Xiamen University News, March 25, 2014. 